\title{
"The mediating effect of job satisfaction on health and safety policy management and employee productivity in manufacturing firms"
}

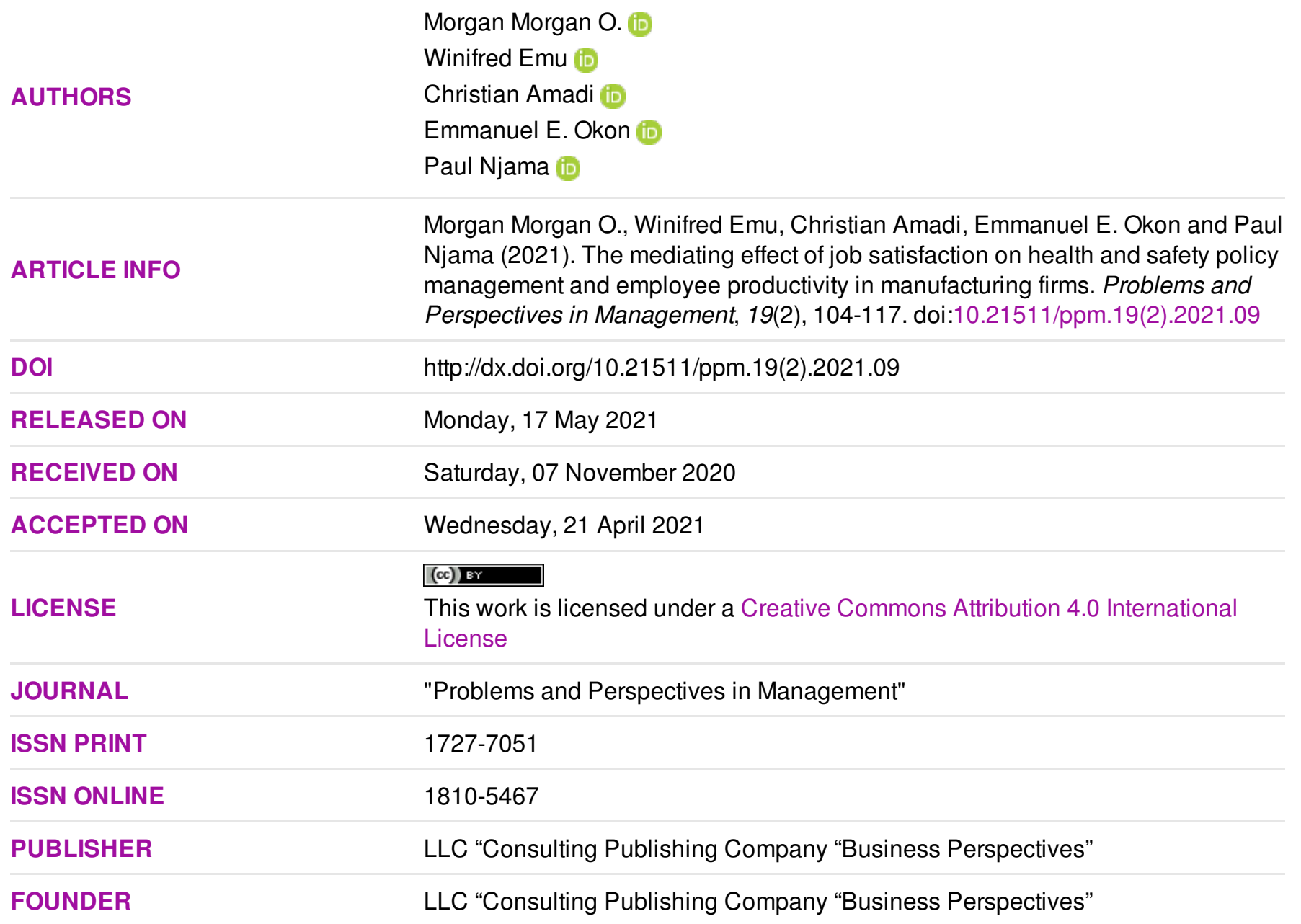

NUMBER OF REFERENCES

46

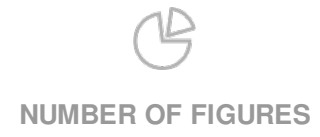

1
NUMBER OF TABLES

7

(C) The author(s) 2021. This publication is an open access article. 


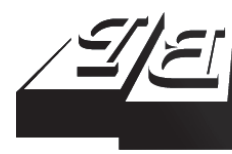

\section{BUSINESS PERSPECTIVES}

0

LLC "CPC "Business Perspectives"

Hryhorii Skovoroda lane, 10,

Sumy, 40022, Ukraine

www.businessperspectives.org
Received on: $7^{\text {th }}$ of November, 2020

Accepted on: $21^{\text {st }}$ of April, 2021

Published on: 17th of May, 2021

() Morgan Morgan O., Winifred Emu, Christian Amadi, Emmanuel Okon,

Paul Njama, 2021

Morgan Morgan O., Ph.D., Lecturer, Business Management Department, Faculty of Management Sciences, Business Management Department, University of Calabar, Nigeria. (Corresponding author)

Winifred Emu, M.Ed., Ph.D. Candidate, Assistant Lecturer, Educational Management Department, Faculty of Education, University of Calabar, Nigeria.

Christian Amadi, Ph.D., Senior Lecturer, Business Administration Department, Faculty of Management, Federal University Wukari, Nigeria.

Emmanuel Okon, Ph.D., Lecturer, Business Management Department, Faculty of Management Sciences, University of Calabar, Nigeria.

Paul Njama, M.Sc., Ph.D. Candidate, Business Management Department, Faculty of Management Sciences, University of Calabar, Nigeria.
Morgan Morgan O. (Nigeria), Winifred Emu (Nigeria), Christian Amadi (Nigeria), Emmanuel Okon (Nigeria), Paul Njama (Nigeria)

\section{THE MEDIATING EFFECT OF JOB SATISFACTION ON HEALTH AND SAFETY POLICY MANAGEMENT AND EMPLOYEE PRODUCTIVITY IN MANUFACTURING FIRMS}

\begin{abstract}
The study investigated the mediating effect of job satisfaction on health and safety policy management and employee productivity in manufacturing firms in Nigeria. For the study, a quantitative analytical method was adopted, including a descriptive survey. To obtain data for the study, a questionnaire instrument was constructed and distributed among 950 sampled respondents in selected manufacturing firms in Nigeria. The descriptive statistics was deployed in the data analysis, while the multiple regression analysis was used to test the study hypotheses at the 0.05 level of significance. The mediating effect of job satisfaction on health and safety policy management and employee productivity relationship was confirmed using the Sobel test with the aid of MedGraph. The results showed that hazard prevention and control policy have a significant positive effect on employee productivity. Risk assessment policy have a significant positive effect on employee productivity. Also, job satisfaction has a significant positive mediating effect on the health and safety policy management and employee productivity relationship. Therefore, manufacturing firms should take appropriate measures to prevent and control hazards and provide effective risk assessments to improve health and safety policy management.
\end{abstract}

Keywords

job satisfaction, health, safety policy management, employee productivity, risk assessment, hazard prevention

JEL Classification I12, J24, J28

\section{INTRODUCTION}

Increasing the productivity of manufacturing firms lies within the milieu of the human element. There is no doubt that the human element in organizations, particularly manufacturing firms, is the most useful asset (Nnadozie \& Ugwu, 2016). Therefore, its efficient utilization will expectedly lead to improved performance and productivity. While many manufacturing firms admit this fact, some still do not understand that, as a vital component in managing a firm's human element, it is essential for managers to ensure that staff performs their duties in a healthy and safe milieu that can stimulate their optimal performance, job satisfaction, and productivity.

Globally, in almost all manufacturing companies, the work environment is susceptible to health and safety hazards due to the high utilization of machines, tools, chemicals, and other dangerous materials in the production processes, which increases health and safety hazards and, as a consequence, affects the employee productivity. These machines, tools, and chemicals, coupled with the highly susceptible 
work environment of most manufacturing firms, oblige employees to perform their duties with cautions, avert accidents and achieve envisaged productivity (Mwangi \& Waiganjo, 2017). The work environment provided by organizations in the manufacturing sector is anticipated to follow the guidelines on health and safety, as well as the emerging global pattern of a safe workplace. Conversely, in the African continent, the increasing figures of fatal accidents, injuries, and other kinds of casualties in manufacturing firms, annually resulting in rising damages to property, lives, and other assets, indicates that the work environment is still unsafe. This situation underscores the relevance of proper health and safety policy management to reduce or eliminate accidents, and to improve employee's welfare and productivity in manufacturing firms in the African continent and in Nigeria in particular. It should be emphasized that accidents are detrimental to workers' job satisfaction and productivity, which influences both workers and a firm. Thus, when workers are contented with the safety in the work organization, accidents can be evaded, thereby guaranteeing workers' safety needs, job satisfaction, and improved productivity (Wachter \& Yorio, 2014).

Although the relevance of adequate safety practices has been well documented (Katsuro et al., 2010), some manufacturing firms' actions and inactions, particularly those in developing nations like Nigeria, still focus mainly on profitability, with little or no attention on the proper management of health and safety policy towards guaranteeing workers safety and enhanced productivity. With the rising economic activities and the resultant upsurge in work-related accidents and exposure to hazardous substances, the relevance of safety and health policy management has continued to be an obvious issue of debate. Furthermore, in Southern region of Nigeria, employees in manufacturing firms are frequently exposed to work-related threats such as dust, chemicals, noise, poor ventilation, high temperature and a host of other inclement conditions, which impaired workers' health and influence their job satisfaction and productivity. An ideal manufacturing facility is an environment where the fundamental safety canons or ideologies are upheld in safeguarding workers from potentially detrimental behaviors or risk in the discharge of their duties.

However, despite the apparent need to manage health and safety policy proactively, manufacturing firms in Nigeria are yet to address the issues of employee health and safety adequately, thereby, resulting in frequent accidents, injuries, illnesses and absenteeism; leading to loss of production time, reduction in product quality, decreased workers job satisfaction and production inefficiency. Also, apart from the willful circumvention and poor attitude towards health and safety, some employees are not aware of the implications of non-adherence to safety and health precautions due to inadequate knowledge. Indeed, any safety and health policy management requires a financial obligation, however, where management of firms view the safety of staff as insignificance and fails to budget adequately for the execution of hazard prevention and control, as well as risk assessment, it could be detrimental to the accomplishment of safety goals (Nnadozie \& Ugwu, 2016). Employee job satisfaction is also an essential ingredient towards the success of any business. Thus, keeping employee satisfied should be a major priority for every employer. While this sounds as a known fact in management practices, most employers fail to provide workers with safe working environment that could guarantee their safety needs and, hence, job satisfaction. Therefore, this study focuses on the mediating effect of job satisfaction on health and safety policy management and employee productivity in manufacturing firms.

\section{LITERATURE REVIEW}

\subsection{Safety and health policy management}

Safety and health policy management aims to minimize the hazard to workers' health from dangerous substances in occupational settings and to avert work-related sicknesses and mishaps. Gbadago et al. (2017) described workers' safety and health as an area that focuses on securing the health of employees and visitors who may be influenced by hazards in the work setting. An organization's health and safety policy management system contains several components such as hazard prevention and control, risk assessment, safety 
training, safety monitoring, and enforcement and accident reporting and investigation, etc. However, management of an organization must be committed to implementing all the elements of a firm's health and safety policy, to achieve health and safety goals of protecting workers from accidents and injuries, as well as satisfied workers' safety needs (Agbola, 2012). Safety and health policy is concerned with protecting employees in the work environment against hazards, illness, and diseases (Akanji \& Lawal, 2012). It is important to have clearly stated safety regulations in manufacturing firms to exhibit administration concern to the safety of staff from risks at occupational milieu. Occupational safety policy specifies a firm safety goal, objective, and duties of personnel to ensure the accomplishment of the firm's safety objectives (Aswathappa, 2005).

As indicated by the International Labour Organization (2019), health and safety focus on the advancement of explicit measures and plans targeted at ensuring workers' safety in the workplace. Work-related health and safety is a procedure for guaranteeing that employees remain protected in the work environment while ensuring their ability to perform assigned duties effectively (Agwu, 2012). An organization's health and safety policy is a written declaration that usually comprises elements of safety programs, detailing how safety will be managed, procedure directed towards preventing or eliminating hazards in the workplace, and a demonstration of organizations' management commitment to employee wellbeing (Armstrong, 2010). Health and safety hazard must be evaluated and managed in a work setting to accomplish the aims of protecting workers (Nnadozie \& Ugwu, 2016).

Similarly, a healthy and secure occupational setting is fundamental in enhancing job satisfaction and improved workers' productivity in an organization (Aswathappa, 2005). The protection of workers is an indispensable component of manufacturing, since the staff of such corporations can only perform optimally when they are healthier and have a safe condition of work (Apeksha, 2016). Safety is essential in any organization to enhance workers' confidence in their working milieu (Badekale, 2012). In manufacturing firms where huge tool is utilized for production, it is anticipated that the rate of health-related hazards will be higher. This is because of the extreme temperature, noise, dust, and gases, etc., generated by this equipment during manufacturing, which exposes staff to accidents and other health-related hazards. Improving employee health and safety is directly linked to their job satisfaction and productivity (Goetzel et al., 2001). It is a general belief that workers carry out their duties optimally when they are healthier and have a conducive environment to work, which in turn leads to high performance and productivity (Lucchini \& Landrigan, 2015).

\subsection{Hazard prevention and control policy}

Hazard prevention and control policy is a major component of an organization's health and safety policy management, which stipulates procedures for preventing and controlling hazards, minimizing or eliminating accidents, reducing adverse health effect and controlling damage to plant and equipment (Ali, 2016). Jonathan and Mbogo (2016) described hazard as something that can be identified and managed as a potential source of danger, for instance, a rotating machine, naked electric cables, an uncovered petrol tank or chain, and a leaking dust extractor, etc.

According to Armstrong (2010), hazard inhibition and management schemes are planned in line with the prevalent safety conditions at an enterprise. Similarly, Jonathan and Mbogo (2016) indicated that hazards could lead to mishaps as a result of dangerous substances or equipment in the workplace. Lucchini and Landrigan (2015) classified hazard into four kinds to include physical hazards, such as noise, radiation, high temperature or poor illumination, etc.; biological hazards, such as infectious waste, viruses, bacteria, etc.; chemical hazards, such as dust, fumes, gasses, etc., and ergonomic hazards such as repetitive motion, poorly designed machinery and tools, poorly designed work practices, or poorly designed equipment and furniture. Furthermore, hazard has to do with situations or actions that, whenever left uncontrolled, may lead to injury or sickness. Recognizing threats and averting or managing them could avoid mishaps (Ali, 2016). As Manduku and Munjuri (2017) indicate, hazard prevention and control policy stipulate safety guidelines for firms in manag- 
ing identified dangers. This includes attempting a hazard-free or fewer dangerous alternative. Employers can manage identified hazards in the work environment by taking measures to prevent and control the hazards (Boyle, 2012).

\subsection{Risk assessment policy}

Risk assessment policy is a vital aspect of safety and health policy management, which enhances proper identification and evaluation of risk factors in the work environment (Karakhan \& Gambatee, 2018). Risk assessment policy stipulates the rate in which assessment of risk is carried out in the organization. It describes the overall process where an organization identifies dangers and protects staff. It is the management of the identification, evaluation, and estimation of the levels of risks involved in a work environment (Boyle, 2012). As indicated by Karakhan and Gambatee (2018), risk evaluation comprises an independent appraisal of dangers in the workplace for effective management. The evaluation process covers the identification of threats, frequency of accidents, and approaches to relieve or diminish the likelihood of the hazard. It additionally includes the documentation of hazard appraisal, its discoveries, and the formulation of strategies to manage the identified threat. Karakhan and Gambatee (2018) indicated that risk assessment policy management is a process of evaluating, recognizing and managing dangers in the workplace in a timely manner.

Furthermore, an adequate risk evaluation technique depends on a progression of stages, including recognizing dangers, appraising the degree of the threat, deciding the technique to adapt in decreasing the threat and accessing the effectiveness of the entire stages of risk assessment (Bankole \& Ibrahim, 2012). The two kinds of risk assessment are quantitative and qualitative (Odeku, 2014). Quantitative evaluation is a direct risk evaluation based on data obtained from the workplace, while qualitative is based on the judgment of the efficacy of the risk. Risk assessment helps to identify hazards and activities where hazards occur. Firm's management are expected to evaluate occupational milieu to identify threats before the commencement of duties to guarantee personnel safety (Perera, 2019).

\subsection{Job satisfaction}

Job satisfaction is fundamental to the accomplishment of enterprise aims. Workers' contentment is associated with higher productivity (Fassoulis \& Alexopoulos, 2015). Therefore, ensuring workers' job satisfaction is significant for business success and performance. While this sounds like a well-established truth, most employers fail to give staff a protected workplace that could ensure their safety needs and hence job satisfaction (Kaynak et al., 2016). Job satisfaction is a frame of mind that the staff has about their work and depends on various components in the work setting. It is also seen as the affective inner feelings workers have about their job (Sembe \& Ayuo, 2017).

Accordingly, Yusuf et al. (2012) see job satisfaction as a positive mind-set of staff towards their work and working conditions. Armstrong (2010) portrays job satisfaction as the frame of mind and emotions individuals have about their occupation. Workers' job satisfaction is the feeling, attitude, and importance workers attach to their occupation (Gyekye, 2005). As indicated by Aiken et al. (2001) adequate health and safety policy management guarantees workers safety needs, job satisfaction, and improved productivity. Also, Fassoulis and Alexopoulos (2015) emphasized that health and safety increase employee job satisfaction and lead to increased productivity.

\subsection{Employee productivity}

Employee productivity is the total factor productivity of employees within a specific time in an organization. It is a measure of quality, quantity, time, and efficiency of employees, machines, and the factory system, etc., in converting inputs into useful outputs (Shannon et al., 2001). Employee productivity is considered a principal source of business growth and competitiveness. Productivity growth constitutes an essential element for measuring the total factor of the productive capacity of an organization.

In most organizations, productivity serves as an appraisal of the proficiency of personnel; also, the efficiency of the enterprise relies on the performance of individual workers. As indicated by Mihiravi and Perera (2017), staff productivity is 
significant for enhancing the achievement of enterprise objectives. A firm's efficiency is the capacity to produce or manufacture a product that meets the customer's desire. Employee productivity influences a firm's profitability, as well as its survival and growth (Lamm et al., 2007). However, safe and healthy working condition could enhance employee's job satisfaction and improve productivity (Faragher et al., 2005).

\subsection{Theoretical background}

As postulated by the human behavior theorist, Maslow, safety is an essential human need. He utilized the themes of physiological, safety, social, esteem, and self-actualization needs to illustrate the paradigm of human motivations (Weihrich \& Koontz, 2005). Maslow postulates that the rudimentary desires of people are structured in a pyramid of prepotency and probability of disappearances ascending from the lowest to the highest. However, safety needs include actual safety at work, emotional injuries, illness, accident, hazards, disease, personal security, and dangers in the work environment (Wachter \& Yorio, 2014). The sense of harmless working condition is a significant element in improving job satisfaction and increase employee productivity (Eric, 2015). Under occupational milieu, employee safety and health can be described as the non-existence of accidents or infection from employees' work environment (Akpan, 2011). Occupational safety and health focus on the formulation and implementation of a specific policy intended to keep workers away from getting hurt or harm in the cause of carrying out their assigned responsibilities, thereby enhancing their productivity (Bertera, 1990).

Similarly, in an attempt to satisfy workers' safety needs, most organizations, especially manufacturing firms, formulate health and safety policies to guarantee their employees' safe work environment capable of ensuring the absence of accidents, injuries, and disease, as well as improving the wellbeing of employees to carry out the assigned task efficiently and improve productivity in organizations (Akpan, 2011). Therefore, the relevance of Maslow's hierarchy of needs theory in the study was that providing adequate health and safety policy and programs and effectively managing their implementation process could guarantee the safety needs of employees, ensure safe and conducive work environment, reduce the number of accidents and boost workers morale for improved productivity.

\section{AIMS AND HYPOTHESES}

The aim of the study is to examine the job satisfaction mediating effect on health and safety policy management and employee productivity in Nigerian manufacturing firms. Specifically, the study hypothesizes that:

1) hazard prevention and control policy have a significant effect on employee productivity;

2) risk assessment policy has a significant effect on employee productivity; and

3) job satisfaction has a significant mediating effect on the relationship between health and safety policy management and employee productivity.

\subsection{Hypothesis formulation}

Based on the reviewed literature, the following hypotheses were put forward:

$H_{1}: \quad$ Hazard prevention and control policy has a significant effect on employee productivity.

$\mathrm{H}_{2}: \quad$ Risk assessment policy has a significant effect on employee productivity.

$H_{3}: \quad J o b$ satisfaction has a significant mediating effect on the relationship between health and safety policy management and employee productivity.

\section{METHOD}

The study used the ex-post facto design, including a descriptive survey. The study was carried out in registered manufacturing firms by the Manufacturers Association of Nigeria (MAN) in Southern Nigeria. The population of the study consisted of all 1,173 employees spread across 18 selected manufacturing firms that operated in all six states of Southern Nigeria. 
A stratified sampling technique was employed. To ensure equal representation of manufacturing firms in the Six South-South States, the study area was subdivided into six strata based on the six states in the area. The random sampling technique was adopted to select three manufacturing firms, each from the six States in the Southern region of Nigeria, making a total of 18 manufacturing firms for the study. Taro Yamane formula was applied to the population of each of the 18 selected manufacturing firms in the six states to determine the sample size of 950 for the study. This was necessary to ensure adequate representation of the staff population in each of the selected manufacturing companies without being bias. Data for the research were collected from primary sources through a questionnaire instrument.

The scope of health and safety policy management was measured by two constructs, hazard prevention and control policy, and risk assessment policy. Employee productivity was the dependent variable, while job satisfaction was the mediating variable. A questionnaire measurement instrument was used. The exploratory factor analysis, in particular Principal component analysis (PCA), was used to validate the constructs in the measurement instrument, and descriptive statistics was deployed in the data analysis. Multiple regression analysis was used to test hypotheses formulated for the study at the 0.05 significance level, and the mediating effect of job satisfaction on health and safety policy management and employee productivity relationship was confirmed using the Sobel test. The analysis was aided by SPSS software version 23 and MedGraph version 3.0. However, before testing hypotheses, preliminary data cleaning and multivariate assumption tests were performed to ensure that the assumptions of the regression analysis were satisfactorily met. The necessary preliminary analysis performed includes descriptive statistics, a test for outliers and normality, a test of homoscedasticity, a linearity test, and a multicollinearity test, respectively.

\section{RESULTS}

Table 1 presents descriptive statistics for the constructs of the study. The report covered data obtained from 950 respondents. The minimum response to the items for each variable was one (strongly disagree), while the maximum was five (strongly agree). The mean of all the variables was well above 2.5 , indicating a positive answer to questions. Standard deviations that were all below one meant that the responses were clustered around the mean. The variances of the distributions indicated that the spread of data was adequate.

\subsection{Results of outliers and normality test}

Outliers can have a disproportionate influence on the regression results. However, as part of the data cleansing procedures, data gathered for analysis in the study were checked for likely multivariate outliers. Hair et al. (2010) propose the use of Mahalanobis Distance $\left(\mathrm{D}^{2}\right)$ to identify whether there were possible outliers in the data set. The Mahalanobis Distance value was compared with the Chi-square distribution for the same degree of freedom. The result showed that only one case had a Mahalanobis Distance probability value above 0.001 . This indicates an outlier and was deleted accordingly. The remaining 949 cases had values lower than 0.001 and were retained. Hence, the dataset was free of outliers.

To determine whether the properties of the dataset were normal, a normality test was carried out. As indicated by Hair et al. (2010), data for regression analysis should be normally distributed. According to Davcik (2014), the rule of thumb for normality of data is that the skewness and kurtosis should not exceed +2.58 and +7 , respectively. Table 2 presents the normality test for the distribution. Skewness and Kurtosis were

Table 1. Descriptive statistics of variables

\begin{tabular}{|c|c|c|c|c|c|c|}
\hline Variables & $\mathbf{N}$ & Minimum & Maximum & Mean & Std. deviation & Variance \\
\hline $\begin{array}{l}\text { Hazard prevention and control } \\
\text { policy }\end{array}$ & 950 & 1 & 5 & 4.3538 & .32551 & .106 \\
\hline Risk assessment policy & 950 & 1 & 5 & 4.3785 & .26641 & .071 \\
\hline Job satisfaction & 950 & 1 & 5 & 4.3967 & .38383 & .147 \\
\hline Employee productivity & 950 & 1 & 5 & 4.4038 & .38672 & .150 \\
\hline Valid N & 950 & & & & & \\
\hline
\end{tabular}


Table 2. Summary of normality test results

\begin{tabular}{|c|c|c|c|c|c|}
\hline Variables & N statistic & $\begin{array}{c}\text { Skewness } \\
\text { statistic }\end{array}$ & Std. error & $\begin{array}{l}\text { Kurtosis } \\
\text { statistic }\end{array}$ & Std. error \\
\hline Hazard prevention and control policy & 949 & -.626 & .079 & -.602 & .159 \\
\hline Risk assessment policy & 949 & -.201 & .079 & -1.071 & .159 \\
\hline Job satisfaction & 949 & -.692 & .079 & -1.089 & .159 \\
\hline Employee productivity & 949 & -.781 & .079 & -.928 & .159 \\
\hline Valid N & 949 & & & & \\
\hline $\mathrm{KMO}$ & .921 & & & & \\
\hline BTS Approx. Chi-Sq & 17559.843 & Df & 55 & Sig & .000 \\
\hline
\end{tabular}

established for all the constructs in the study. The result shows that all the variables satisfied the condition for normality as all the skewness and kurtosis of the variables did not exceed +2.58 and +7 . To further confirm the normality of the dataset, the Kaiser-Meyer-Olkin (KMO) and Bartlett's Test of Sphericity (BTS) were executed. The rule of thumb for these tests is that the KMO should be greater than 0.6, and the probability value ( $\mathrm{p}$-value) should be below 0.05 . The results in Table 2 confirmed that the dataset had normal properties.

\subsection{Results of homoscedasticity and multicollinearity test}

In conducting the homoscedasticity test, Levene's test of equality of variances was conducted to determine if the variables were homoscedastic. The results of Levene's test in Table 3 were not significant across all the variables $(p>0.05)$, indicating that there was homogeneity of variance among the variables. Also, multicollinearity test was executed using tolerance value and Variance Inflation Factor (VIF) to see whether there were very high intercorrelations or inter-association among the predictor constructs. The rule of thumb is that tolerance should not be lower than 0.10 and VIF should not be above 10 (Hair et al., 2010). The results in Table 3 revealed that there were no multicollinearity issues as the tolerance values were all above .10 and VIF were far less than the cut-off value of 10 .

\subsection{Results of exploratory factor analysis and reliability test}

Exploratory factor analysis describes the procedure for evaluating the structure of variables in a study and data reduction technique necessary to streamline variables to a manageable number (Hair et al., 2010). It is a data streamlining technique that streamlines multiple variables into fewer ones that adequately represent the constructs. According to Hair et al. (2010), the purpose of exploratory factor analysis is the reduction and summarization of data using either factor analysis or principal component analysis. However, to ascertain the content validity of the questionnaire constructs, the exploratory factor analysis, in particular Principal Component Analysis (PCA), was performed. This was necessary because PCA focuses on the minimum quantity of factors that accounts for variance in variables and whose specific variance represents a small fraction of the variance in the variable.

In terms of factor rotation, the Orthogonal Varimax rotation was utilized, since it offers a better delineation of factors. However, the number of factors to retain in the model was determined by the criteria for assessing validity according to Hair et al. (2010) as follows: Intercorrelations >.30; Kaiser-Meyer-Olkin (KMO) >.50; Bartlett's test of sphericity <.05; Measure of sample adequacy $>.50$; Factor loading (Component Matrix) $>.50$; Total variance explained $>60$ percent; and Eigenvalues $>1$. The PCA analysis satisfactorily meets all the set

Table 3. Homoscedasticity and multicollinearity test

\begin{tabular}{l|c|c|c|c|c}
\hline \multicolumn{1}{c|}{ Variables } & $\begin{array}{c}\text { Levene } \\
\text { statistic }\end{array}$ & Df1 & Df2 & Sig. & $\begin{array}{c}\text { Collinearity statistics } \\
\text { Tolerance }\end{array}$ \\
\hline Hazard prevention and control policy & 1.531 & 1 & 947 & .216 & .525 \\
Risk assessment policy & .461 & 1 & 947 & .498 & .404 \\
\hline Job satisfaction & .290 & 1 & 947 & .590 & .506 \\
Employee productivity & 1.916 & 1 & 947 & .237 & .511 \\
\hline
\end{tabular}


Table 4. Summary of exploratory factor analysis and reliability test results

\begin{tabular}{|c|c|c|c|c|c|}
\hline Variables & No. of items & KMO & Bartlett's test & Variance explained & Cronbach's coefficient \\
\hline Hazard prevention and control policy & 5 & 0.681 & Significant & 73.291 & 0.725 \\
\hline Risk assessment policy & 6 & 0.503 & Significant & 72.988 & 0.741 \\
\hline Job satisfaction & 5 & 0.714 & Significant & 73.746 & 0.730 \\
\hline Employee productivity & 6 & 0.582 & Significant & 63.866 & 0.744 \\
\hline
\end{tabular}

criteria. Table 4 presents a summary of the factor analysis and Cronbach alpha coefficient reliability test, which indicated that all the variables met reliability criterion and were valid and reliable for the use in the analysis.

\subsection{Hypothesis results}

Multiple regression analysis was used to determine the relationship between health and safety policy management and employee productivity, and to validate hypotheses $H_{1}$ and $H_{2}$ of the study. Health and safety policy management was measured by hazard prevention and control policy and risk assessment policy. The two variables of health and safety policy management were regressed against employee productivity. The results in Table 5 indicate a strong and significant positive relationship between safety and health policy management variables and employee productivity $(p=0.000)$. The coefficient of multiple determination as indicated by the Adjusted $R^{2}$ in Table 5 showed that the regressands were able to explain $66 \%$ of variations in employee productivity.
The overall significance of the model carried out through the ANOVA F-test in Table 5 showed a value of 920.958 , and was found to be significant at $0.05(p=0.000)$, thus ascertaining the validity of the overall model. However, the results of the coefficients in Table 5 were as follows: 0.466 and 0.741 on hazard prevention and control policy and risk assessment policy, respectively. These results indicate that when hazard prevention and control policy and risk assessment policy increase by one percent, employee productivity increases by 0.466 and 0.741 percent, respectively. The model coefficients result shows that the $\mathrm{t}$-tests of all the variables had a $\mathrm{p}$-value below $0.05(p=0.000)$ in hazard prevention and control policy and risk assessment policy, respectively, indicating that the health and safety policy management variables used in the study had a statistically significant effect on employee productivity. Therefore, this result validated hypotheses $H_{1}$ and $\mathrm{H}_{2}$ of the study that hazard prevention and control policy and risk assessment policy has a significant positive effect on employee productivity in manufacturing firms.

Table 5. The result of multiple regression analysis for hypothesis testing

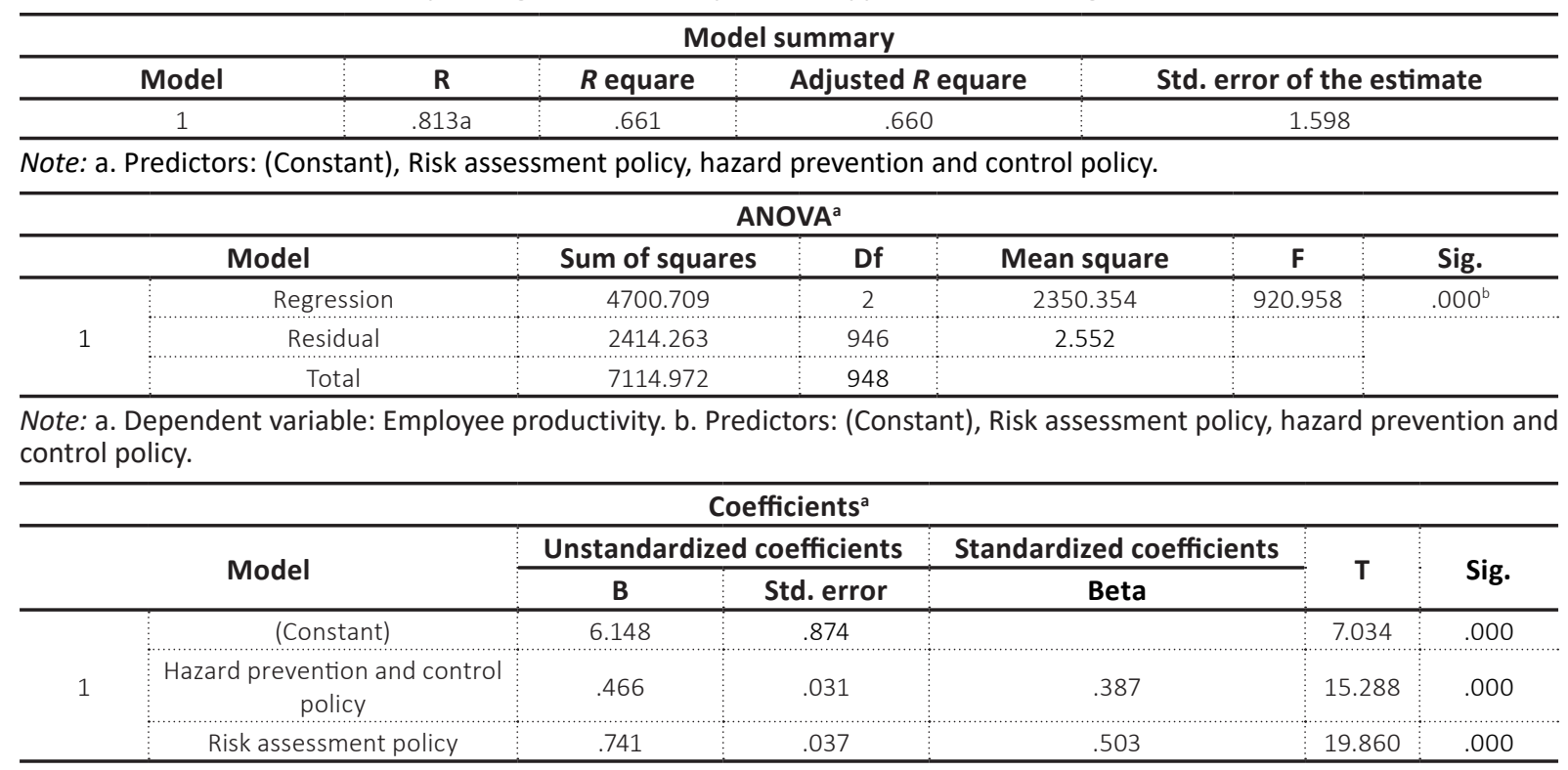

Note: a. Dependent variable: Employee productivity. 
Table 6. Summary of regression results for the variables

\begin{tabular}{|c|c|c|c|c|c|}
\hline Regression & $R^{2}$ & $\mathbf{F}$ & Beta & $\mathbf{T}$ & Sig. \\
\hline $\mathrm{HSPM} \rightarrow \mathrm{EP}$ & .837 & 4852.950 & .915 & 69.663 & .000 \\
\hline $\mathrm{JS} \rightarrow \mathrm{HSPM}$ & .789 & 3547.434 & .888 & 59.560 & .000 \\
\hline $\mathrm{EP} \rightarrow \mathrm{HSPM} / \mathrm{JS}$ & 919 & 5379.404 & .359 & 17.826 & .000 \\
\hline $\mathrm{JS} \rightarrow \mathrm{EP}$ & .892 & 7823.867 & .944 & 88.453 & .000 \\
\hline
\end{tabular}

Note: Significant at <.001; HSPM = Health and Safety Policy Management, EP = Employee Productivity, and JS = Job Satisfaction.

A series of regression analyses were performed to examine the mediating effect of job satisfaction on the relationship between health and safety policy management and employee productivity, as shown in Table 6 . First, the direct effect was determined between the independent variable (health and safety policy management) and the dependent variable (employee productivity), the result was significant $(b=0.915, \mathrm{t}=69.663, p<0.000)$. Second, the mediating variable (job satisfaction) was regressed with independent variable (health and safety policy management), and the result was significant $(b=0.888, t=59.560, p<0.000)$. Third, the dependent variable (employee productivity) was regressed with the independent and mediating variables (health and safety policy management and job satisfaction), and the result was significant $(b=0.359, t=17.826, p<0.000)$. Finally, the mediating variable (job satisfaction) was regressed against employee productivity, the result was significant $(b=0.944, t=88.453, p<0.000)$.

To test the mediating effect of job satisfaction on the relationship between health and safety policy management and employee productivity, and to validate hypothesis $\mathrm{H}_{3}$ of the study, Sobel test was used with the aid of Jose (2013) MedGraph to depict the mediation among the three constructs in the study (job satisfaction, health and safety policy management and employee productivity). To ascertain whether there is significant mediation of job satisfaction on the relationship between health and safety policy management and employee productivity based on the significance of the Sobel's z- score, the rule of thumb is that the obtained $p$-value of the Sobel's z-score should be less than 0.05 and a $95 \%$ confidence interval with upper and lower values. If the range of the upper and lower values includes zero, there is non-significant mediation, but if the range does not include zero, there is significant mediation (Jose, 2013).

The results in Table 7 showed a Sobel z-score of 10.629412 and a $p$-value of $p=<0.000001$, which is less 0.05 . Also, the results in Table 7 revealed a 95\% confidence interval with upper and lower values of .17711 and .25721 , respectively. These results indicated that there is a significant mediation of job satisfaction on the relationship between health and safety policy management and employee productivity. Therefore, the result validated hypothesis $H_{3}$ of the study that job satisfaction has a significant positive mediating effect on health and safety policy management and employee productivity relationship.

Table 7. Results of the Sobel test for the mediating effect

\begin{tabular}{|c|c|c|}
\hline Significance of mediation & & Significant \\
\hline Sobel z-value & 10.629412 & $p=<0.000001$ \\
\hline \multicolumn{3}{|c|}{ 95\% Symmetrical confidence interval } \\
\hline Lower & .17711 & \\
\hline Upper & .25721 & \\
\hline \multicolumn{3}{|c|}{ Unstandardized indirect effect } \\
\hline$a * b$ & .21716 & \\
\hline $\mathrm{Se}$ & .02043 & \\
\hline \multicolumn{3}{|c|}{ Effect size measures } \\
\hline Standardized coefficients & & $R^{2}$ Measures \\
\hline Total: & .563 & 000 \\
\hline Direct: & .741 & .357 \\
\hline Indirect: & .294 & .713 \\
\hline Indirect to Total Ratio: & .521 & .666 \\
\hline
\end{tabular}




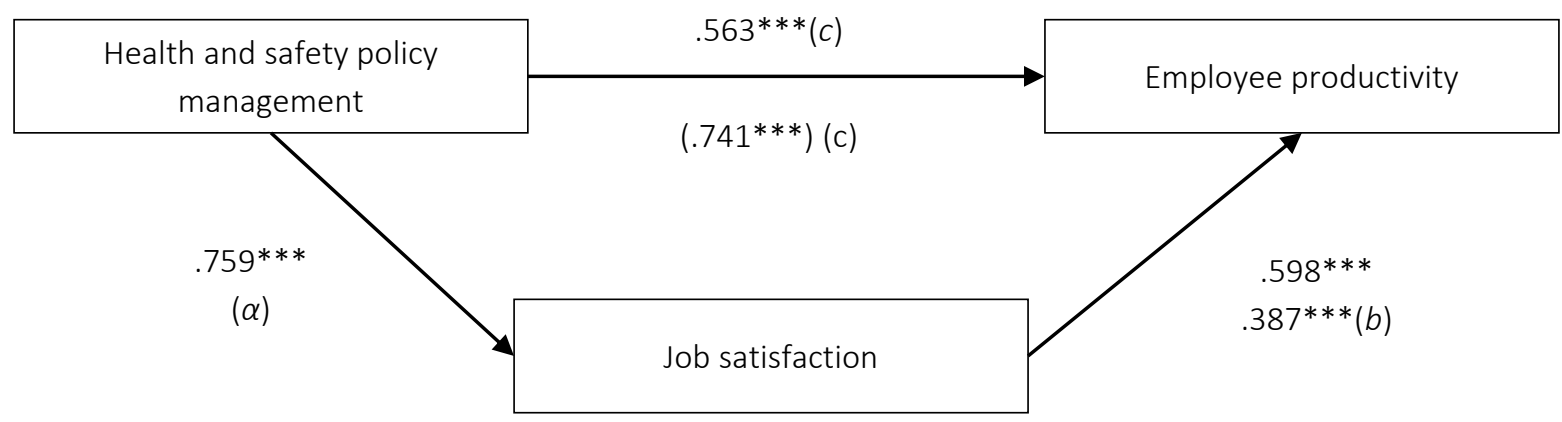

Figure 1. Standardized coefficients of the mediating effect

Figure 1 presents the standardized coefficients of the mediating effect of job satisfaction on the relationship between health and safety policy management and employee productivity. Figure 1 revealed 0.741 and 0.598 beta weights computed after the inclusion of the mediator job satisfaction and zero order correlations values of $0.563,0.387$, and 0.759 , respectively. The standardized coefficients beta weights of 0.741 and 0.598 indicated that the indirect path from health and safety policy management through job satisfaction to employee productivity accounted for about $74.1 \%$ and $59.8 \%$ of the total effect, respectively.

\section{DISCUSSION}

The test of hypotheses $H_{1}$ and $H_{2}$ revealed a coefficient of multiple determination as indicated by the Adjusted $\mathrm{R}^{2}$, which showed that the regressands were able to explain $66 \%$ of the variations in employee productivity. The general significance of the model carried out through ANOVA F-test showed a value of 920.958 , and was found to be significant at $0.05(p=0.000)$, thus ascertaining the significance of the overall model. The result of the model coefficients showed that the two constructs of health and safety policy management (hazard prevention and control policy and risk assessment policy) used in the study had significant values below $0.05(p=0.000)$, respectively, indicating a significant positive influence of the constructs of safety and health policy management on employee productivity. This implies that hazard prevention and control policy and risk assessment policy has a significant positive effect on employee productivity in the selected manufacturing firms.
This finding was supported by Badekale (2012) whose similar study on the influence of organizational safety policy on employee performance in Larfarge (WAPCO) Ewerkoro found that safety policy significantly influences workers' efficiency. The finding was also supported by Odeku (2014) who found that hazard control measures play a vital role in accident reduction in organizations and that personal protective equipment and engineering control techniques significantly affect the rate of accidents in firms. Also, the finding was supported by Karakhan and Gambatee (2018) who found that hazard evaluation, control, and monitoring had a significant positive impact on accident reduction in firms. Similarly, the finding was in line with the finding of Perera (2019) that safety and health significantly influence accident reduction and employee performance in firms. Again, the research aligned with the study of Eric (2015) who found that safety programs significantly influence workers' productivity.

The test of hypothesis $H_{3}$ revealed that job satisfaction significantly mediates the relationship between health and safety policy management and employee productivity. This finding was reached after a series of regression analysis was performed and the test of the mediating effect executed. The results showed a Sobel $z$-value of 10.629412 and a $p$-value of $p=<0.000001$, which is less than 0.05 , and a 95\% confidence interval with upper and lower values of .17711 and .25721, respectively. These results indicated that there is a significant positive mediation of job satisfaction on the relationship between health and safety policy management and employee productivity. The finding was supported by Yusuf et al. (2012) who found that job satisfaction affects workers' performance. The finding was in line with that of Perera (2019) 
that safety and health are significantly related to job satisfaction among field employees in an organization. Also, the finding was in agreement with the study of Mihiravi and Perera (2017) that safety measures positively correlate with workers' job satisfaction in firms.

\section{CONCLUSION}

This study explored the mediating effect of job satisfaction on health and safety policy management and employee productivity in manufacturing firms. Two health and safety policy management constructs were chosen for the study: hazard prevention and control and risk assessment. The study further examined the mediating effect of job satisfaction on health and safety policy management and employee productivity relationship.

The results from the analyses showed that the two constructs of health and safety policy management positively influenced employee productivity. Specifically, the study concluded that hazard prevention and control policy has a significant positive effect on employee productivity in selected manufacturing firms. Similarly, risk assessment policy has a significant positive effect on employee productivity in the selected manufacturing firms. Also, job satisfaction has a significant positive mediating effect on the relationship between health and safety policy management and employee productivity in the selected manufacturing firms.

Based on the results of the study, it is concluded that proper hazard prevention and adoption of adequate control measures, as well as regular risk assessments, are essential to reduce the rate of occupational accidents and injuries, enhance conducive occupational milieu, and improve workers' welfare and job satisfaction. In other words, proper health and safety policy management would create a feeling of safety and health assurance, boost employees' morale and meet the safety needs of employees for improved productivity. Therefore, it is imperative that the management of manufacturing firms take appropriate hazard prevention and control measures in line with global best practices in their organizations to ensure workers' safety, job satisfaction, and improved productivity.

\section{AUTHOR CONTRIBUTIONS}

Conceptualization: Morgan Morgan O., Emmanuel Okon.

Data curation: Winifred Emu, Christian Amadi, Emmanuel Okon, Paul Njama.

Formal analysis: Morgan Morgan O.

Funding acquisition: Morgan Morgan O., Winifred Emu, Christian Amadi, Emmanuel Okon.

Investigation: Morgan Morgan O., Winifred Emu, Christian Amadi.

Methodology: Morgan Morgan O., Winifred Emu, Emmanuel Okon,

Project administration: Paul Njama.

Supervision: Christian Amadi, Paul Njama.

Writing - original draft: Morgan Morgan O., Emmanuel Okon.

Writing - review \& editing: Winifred Emu, Christian Amadi.

\section{ACKNOWLEDGMENTS}

The authors express gratitude to anonymous reviewers, the journal editor and all the authors whose work were used in this study. The authors are grateful to the management of manufacturing firms included in the study for having given approval for the administration of the questionnaire instrument, and the survey respondents for providing their views on the issues raised in the questionnaire instrument on health and safety policy management (hazard prevention and control policy and risk assessment policy), employee productivity and job satisfaction. 


\section{REFERENCES}

1. Agbola, R. M. (2012). Impact of health and safety management on employee safety at the Ghana Ports and Harbour Authority. Developing Country Studies, 2(9), 156-167. Retrieved from https://www.iiste. org/Journals/index.php/DCS/article/view/2978

2. Agwu, M. O. (2012). Impact of employees' safety culture on organisational performance in Shell Bonny Terminal Integrated Project (BTIP). European Journal of Business and Social Sciences, 1(5), 70-82. Retrieved from https://www. semanticscholar.org/paper/IMPACT-OF-EMPLOYEES-SAFETYCULTURE-ON-PERFORMANCEAgwu/42372a29983cc96166c1672e 7fdaa6f0c57af3d5

3. Aiken, L. H., Clarke, S. P., Sloane, D. M., Sochalski, J. A., Busse, R., Clarke, H., Giovannetti, P., Hunt, J., Rafferty, A. M., \& Shamian, J. (2001). Nurses' reports on hospital care in five countries. Health Affairs, 20(3), 1-11. https://doi.org/10.1377/ hlthaff.20.3.43

4. Akpan, E. I. (2011). Effective safety and health management policy for improved performance of organizations in Africa. International Journal of Business and Management, 6(3), 159-165. https://doi.org/10.5539/ijbm. v6n3p159

5. Ali, W. (2016). Understanding the concept of job satisfaction, measurements, theories and its significance in the recent organizational environment: A theoretical framework. Archives of Business Research, 4(1), 100111. https://doi.org/10.14738/ abr.41.1735

6. Apeksha, E. (2016, December 2223). Contribution of occupational health and safety practices on nonmanagerial employee productivity in the Apparel Industry of Sri Lanka. Proceedings from The $5^{\text {th }}$ International Conference of Sri Lanka forum of University Economist. Sri Lanka.

7. Armstrong, M. (2010). Essential human resource management practice: A guide to people management. London: Konga Page.
8. Aswathappa, K. (2005). Human resource and personnel management. California, USA: Tata McGraw-Hill Education.

9. Badekale, O. F. (2012). Effect of organizational health and safety policy on employees' performance in Larfarge (WAPCO) PLC Ewekoro, Ogun State. Retrieved from https:// www.academia.edu/2462477/ EFFECTS_OF_ORGANIZATIONAL_HEALTH_AND_SAFETY_POLICIES_ON_EMPLOYEES_PERFORMANCE

10. Bankole, A., R., \& Ibrahim, L. O. (2012). Perceived influence of health education on occupational health of factory workers in Lagos, Nigeria. British Journal of Arts and Social Sciences, 8(1), 57-65. Retrieved from https://www.semanticscholar.org/paper/PerceivedInfluence-of-Health-Educationon-Health-Bankole-Ibrahim/3559 46d635f320534cca47239da62430ee693a13

11. Bertera, R. (1990). The effects of workplace health promotion on absenteeism and employment costs in a large industrial population. American Journal of Public Health, 80(9), 1101-1105. https://doi. org/10/2105/ajph.80.9.1101

12. Bockerman, P., \& Ilmakunnas, P. (2010). The job satisfactionproductivity nexus: A study using matched survey and register data (MPRA Paper 23348). Munich: University Library of Munich. Retrieved from https://ideas.repec. org/p/pra/mprapa/23348.html

13. Boyle, T. (2012). Health and safety: Risk management. Leicestershire: International Occupational Health and Safety Services limited Press.

14. Davcik, N. S. (2014). The use and misuse of structural equation modeling in management research: A review and critique. Journal of Advance Management, 11(1), 47-81. https://doi.org/10/1108/JAMR-072013-0043

15. Dwomoh, G., Owusu, E., \& Addo, M. (2013). Impact of occupational health and safety policies on employees' performance in the Ghana's timber industry: Evidence from Lumber and Logs Limited.
International Journal of Education and Research, 1(12), 1-14.

Retrieved from https://ijern.com/ journal/December-2013/38.pdf

16. Eric, O. O. (2015). Effect of occupational safety and health programmes on employee performance at Kenya Power Company Limited. Department of Business Administration, School of Business, University of Nairobi. Retrieved from http://erepository. uonbi.ac.ke/handle/11295/93944

17. Faragher, E. B., Cass, M., \& Cooper, C. L. (2005). The relationship between job satisfaction and health: A meta-analysis. Occupational and Environmental Medicine, 62(2), 105-112. https://doi.org/10.1136/ oem.2002.006734

18. Fassoulis, K., \& Alexopoulos, N. (2015). The workplace as a factor of job satisfaction and productivity. Journal of Facilities Management, 13(4), 332-349. https://doi.org/10.1108/JFM-062014-0018

19. Gbadago, P., Amedome, S. N., \& Honyenuga, B. Q. (2017). The impact of occupational health and safety measures on employee performance at the South Tongu District Hospital. Global Journal of Medical Research, 17(5), 1-8. Retrieved from https://globaljournals.org/GJMR_Volume17/3-TheImpact-of-Occupational-Health. pdf

20. Goetzel, R., Guindon, A., Turshen, I., \& Ozminkowski, O. (2001). Health and productivity management: Establishing key performance measures, benchmarks, and best practices. Journal of Occupational and Environmental Medicine, 43(1), 10-7. https:// doi.org/10.1097/00043764200101000-00003

21. Gonca, K., \& Murat, S. S. (2009). The effects of occupational health and safety risk factors on job satisfaction in hotel enterprises. Ege Academic Review, 9(3), 903921. http://dx.doi.org/10.21121/ eab.2009319693 
22. Gyekye, S. A. (2005). Workers' perceptions of workplace safety and job satisfaction. International Journal of Occupational Safety and Ergonomics, 11(3), 291-302. https://doi.org/10.1080/10803548. 2005.11076650

23. Hair JR, J. F., Black, W. R., Babin, B. J., \& Anderson, R. E. (2010). Multivariate Data Analysis ( $7^{\text {th }}$ ed.). Upper Saddle River, NJ. Prentice Hall.

24. Iheanacho, M. U., \& Ebitu, E. T. (2017). Effects of industrial safety and health on employees' job performance in selected cement companies in Cross River State, Nigeria. International Journal of Business and Management Review, 4(3), 49-56. Retrieved from https:// www.eajournals.org/journals/ international-journal-of-business-and-management-reviewijbmr/vol-4-issue-3-april-2016/ effects-of-industrial-safety-andhealth-on-employees-job-performance-in-selected-cement-companies-in-cross-river-state-nigeria/

25. International Labor Organization. (2019). Safety and Health at the Heart of the Future of Work: Building on 100 Years of Experience. Geneva: International Labour Organization.

26. Jonathan, G. K., \& Mbogo, R., W. (2016). Maintaining health and safety at workplace: Employee and employer's role in ensuring a safe working environment. Journal of Education and Practice, 7(29), 1-7. Retrieved from https://eric. ed.gov/?id=EJ1118861

27. Jose, P. E. (2013). MedGraph: A program to graphically depict mediation among three variables (version 3.0). Victoria University of Wellington, New Zealand. Retrieved from https://psychology. victoria.ac.nz/medgraph/

28. Karakhan, A., \& Gambatee, J. (2018). Hazard and risk in construction and the impact of incentives and rewards on safety outcomes. Practice Periodical on Structural Design and Construction, 23(2). Retrieved from https://ascelibrary.org/doi/abs/10.1061/\%28 ASCE\%29SC.1943-5576.0000359
29. Katsuro, P., Gadzirayi, C. T., Taruwona, M., \& Mupararano, S. (2010). Impact of occupational health and safety on worker productivity: A case of Zimbabwe food industry. African Journal of Business Management, 4(13), 2644-2655. Retrieved from https:// academicjournals.org/article/ article1380720540_Katsuro\%20 et\%20al.pdf

30. Kaynak, R., Toklu, A., Elci1, M., Toklu, I. (2016). Effects of occupational health and safety practices on organizational commitment, work alienation, and job performance: Using the PLS-SEM approach. International Journal of Business and Management, 11(5), 146-166. http://dx.doi.org/10.5539/ijbm. v11n5p146

31. Lamm, F., Massey, C., \& Perry, M. (2007). Is there a link between workplace health and safety and firm performance and productivity? Retrieved from https://search. informit.org/doi/10.3316/INFORMIT.135846714466567

32. Lucchini, R. G., \& Landrigan, P. J. (2015). Occupational health and safety in the expanding economies: Severe challenges and the need for action through education and training. Annals of Global Health, 81(4). http://dx.doi. org/10.1016/j.aogh.2015.08.024

33. Manduku, F., \& Munjuri, M. (2017). Extent of the implementation of the occupational safety and health act 2007 in the Sarova Group of Hotels in Nairobi. International Journal of History and Research, 1(1), 1-17. Retrieved from http:// erepository.uonbi.ac.ke/handle/11295/94149

34. Mihiravi, D. P., \& Perera, G. D. N. (2017, October 8-9). Impact of occupational safety and health practices on job satisfaction: A study in selected large scale Apparel Firms in Colombo District. Proceedings from the $3 r d$ International Human Resource Management Conference. Department of Human Resource Management, University of Sri Jayewardenepura, Sri Jayewardenepura.
35. Mwangi, J., \& Waiganjo, E. (2017). Influence of occupational health and safety on employees' performance in the flower industry in Kenya: A case study of Penta Flowers Limited, Thika SubCounty. The Strategic Journal of Business and Change Management, 4(3), 191-208. Retrieved from https://strategicjournals.com/index.php/journal/article/view/490

36. Ndiyo, N. A. (2005). Foundation of Statistic and Computer Applications. Calabar: Wusen Publishers.

37. Nnadozie, N., \& Ugwu, K. (2016). Evaluating occupational health and safety management in selected plastic Manufacturing organisations in Awka Metropolis Nigeria. Management Studies and Economic Systems, 3(1), 23-33. http://www.msaes.org/ article 40990.html

38. Odeku, K. O. (2014). Industrial accident and safety hazards at the workplace: A spatiophysical workplace approach. Mediterranean Journal of Social Sciences, 5(20), 2949-2953. https:// doi.org/10.5901/mjss.2014. v5n20p2949

39. Perera, G. D. N. (2019). Occupational health and safety practice and job performance: Role of job of satisfaction. Sri Lankan Journal of Human Resource Management, 9(1), 1-10.

40. Sembe, F., \& Ayuo, A. (2017). Effect of selected occupational health and safety management practices on job satisfaction of employees in University Campuses in Nakuru Town, Kenya. Journal of Human Resource Management, 5(5), 7077. https://doi.org/10.11648/j. jhrm.20170505.11

41. Shannon, H. S., Robson, L. S., \& Sale, J. E. M. (2001). Creating safer and healthier workplaces: Role of organizational factors and job characteristics. American Journal of Industrial Medicine, 40(3). https://doi.org/10.1002/ajim.1106

42. Topal, S. (2011). Occupational injuries and occupational safety and health regulations in three industries in North Cyprus, opportunities for improvement 
identified. Retrieved from http://irep.emu.edu.tr:8080/xmlui/bitstream/handle/11129/1456/Topal. pdf? sequence $=1$

43. Wachter, J. K., \& Yorio, P. L. (2014). A system of safety management practices and worker engagement for reducing and preventing accidents: An empirical and theoretical investigation. Accident Analysis and Prevention, 68, 117 130. http://dx.doi.org/10.1016/j. aap.2013.07.029
44. Weihrich, H., \& Koontz, H. (2005). Management: A global perspective (11 ed.). New Delhi: Tata McGraw Hill.

45. Yankson, E. (2012). The effect of health and safety standards on productivity in Ghana Rubber Estates Limited. Kwame Nkrumah University of Science and Technology. Retrieved from http://129.122.16.11/bitstream/123456789/4904/1/Yankson\%20Esi.pdf
46. Yusuf, R. M., Eliyana, A., \& Sari, O. N. (2012). The influence of occupational safety and health on performance with job satisfaction as intervening variables (Study on the production employees in PT. Mahakarya Rotanindo, Gresik). American Journal of Economics (Special Issue). https:// doi.org/10.5923/j.economics. 20120001.30 